\title{
Comment on the Welfare Effect of Foreign Exchange Market
}

\author{
Yonghua Yang ${ }^{\mathrm{a}}$ and Ying Chen ${ }^{\mathrm{b}}$ \\ School of Economics and Management, Yunnan Normal University, Kunming 650500, China \\ ayhyang2003@163.com, b2508428618@qq.com
}

\begin{abstract}
China's current foreign exchange market is a closed market system with many aspects of inter-bank market and foreign exchange transactions. This has caused many problems such as lack of market competition and low efficiency. However, China's foreign exchange market is an important part of China's financial market, and in the perfect exchange rate formation mechanism, to promote the RMB convertible, service financial institutions, to promote changes in macro-control methods and to promote the improvement of the financial market system has played irreplaceable The role. In this paper, the welfare effect of the foreign exchange market is studied from the aspects of trade effect, investment effect, exchange rate stability and monetary internationalization, and the research on the foreign exchange market is reviewed.
\end{abstract}

Keywords: Trade effect, investment effect, exchange rate stability, currency internationalization.

\section{The trade effect of the foreign exchange market}

The famous 1990 "one market, one currency" of the EU report states that one of the main interests of adopting a currency in Europe is the increase in trade. The study shows that the foreign exchange market can facilitate the exchange of different kinds of currencies, can promote the smooth realization of international trade, from three angles to explain the increase in trade between countries: First, the construction of the exchange market increased the vertical division of labor between countries, The production of various stages of production in different countries, thus promoting the country between raw materials, intermediate goods and the final product trade; Second, the construction of foreign exchange market to reduce the cost of cross-border trade, reducing the cost of producing such goods, thus Promote the trade; Third, the existence of the foreign exchange market, so that foreign exchange traders can use the operating technology to avoid foreign exchange risk, to provide buyers, sellers credit and guarantees to promote the normal flow of funds and international trade and international trade continues to expand.

The construction of the foreign exchange market is conducive to the formation of monetary union and currency regionalization in the region. Previous studies have shown that the formation of monetary union can not only promote the trade of the countries within the alliance, but also increase the trade between the alliance and the foreign countries. Andrew K.Rose (2000) pointed out that the implementation of the common currency can increase the trade volume by more than $200 \%$, and the trade volume between the member countries is three times the volume of trade with the non-member countries. Unlike other studies, Rose's research suggests that exchange rate volatility is significantly negatively correlated with trade, while common currency is positively correlated with trade. Baldwin, R. E. (2006) used the OECD 20-year annual data (introduced in Euros in 1999) from 1989 to 2002. The results show that the effect of the euro from 1998 to show, and until the end of the study has been maintained upward trend. Aleksander Aristovnik and Matevz Meze (2010) explored the impact of the euro on trade in euro area member countries, mainly due to the introduction of the euro into international trade in Slovenia.

The construction of the foreign exchange market is conducive to the formation of monetary union, contribute to the regionalization of the RMB and international development has reached a broad consensus. Zhong Yang, Ding Yibing (2012) through the panel model on the international status of the dollar factors for empirical analysis, confirmed the network externalities play an important role. Domestic scholars have studied the impact of RMB regionalization or internationalization on trade. 
The results show that regionalization or internationalization of RMB has a positive impact on the trade of related countries. Li Chong et al. (2002) argue that the regionalization of renminbi can expand the trade between China and neighboring countries or regions, which is conducive to the economic development of both sides. Hu Zongyi and Liu Yewen (2009) analyzed the impact of RMB internationalization on China's import and export trade through the use of China Dynamic Computable General Equilibrium (CGE) model-MCHUGE model. The results show that the internationalization of RMB has a positive effect on the improvement of China's terms of trade, employment and industrial optimization.

\section{Investment Effect of Foreign Exchange Market}

Related research suggests that the construction of the foreign exchange market is conducive to eliminating or reducing the exchange rate fluctuations in the region, from the following three aspects of the region's foreign direct investment:

First, the relative cost of production change. The traditional theory of international investment mainly focuses on the motivations and abilities of foreign investment in multinational corporations, and the influence of exchange rate and its changes on FDI has long been neglected. Even if the exchange rate fluctuates, you can choose a variety of financial derivatives to risk their investment to avoid. Cushman $(1985,1987)$ examines the impact of exchange rate changes on international direct investment from the perspective of relative labor costs, assuming that international direct investment is aimed at finding low labor costs. Relative to the cost of production theory that the exchange rate changes in the production costs of the host country have a certain impact. When other factors remain unchanged, the devaluation of the currency will reduce the local production costs relative to foreign countries, especially labor costs, and this cost reduction will increase the rate of return on capital, thus contributing to FDI.

Second, the wealth effect of exchange rate changes. Froot and Stein (1991) argue that the devaluation of the host currency can improve the relative wealth of foreign investors and thus benefit them from mergers and acquisitions of host countries. However, in recent years, some scholars have found that there is a positive relationship between exchange rate changes and FDI inflows. For the impact of exchange rate volatility on FDI inflows, it is generally considered that the more volatile exchange rate and the risks faced by foreign direct investment the bigger it is. Therefore, the exchange rate fluctuation is too large for the risk avoidance type of investment is detrimental. However, some scholars believe that exchange rate fluctuations and FDI inflows do not have a clear correlation.

Third, the risk aversion under the exchange rate changes. Risk avoidance theory that the greater the exchange rate changes, the expected level of exchange rate equivalent to reduce the more equivalent. The estimate of future profit by the firm in the current investment decision is based on the expected profit function with a deterministic equivalence level. It is possible to test the effect of multiple risk factors in the expected profit by using the exchange rate fluctuation to construct the effect of the expected profit directly to distinguish the exchange rate fluctuation effect and the exchange rate level effect, and to distinguish the exchange rate fluctuation effect and the exchange rate level effect. Codlberg and Kolstad used a simple model to illustrate the relationship between exchange rate fluctuations and the decisions made by multinational producers to set production bases at home and abroad. In this two-phase model, enterprises in the domestic and foreign, Sui production base, but only to the domestic market supply products. In the first period, the level of integration of multinational companies to determine and implement its domestic and international production capacity of the layout. This investment in production capacity indicates the planned size of the parent company: the firm chooses production capacity in two production bases in order to maximize the expected profit. In the second period, the uncertainty of demand and exchange rate has been clear, domestic and foreign production capacity fluctuations in the domestic capital flows to foreign share of the relevant: If the investor is risk neutral, the model did not show exchange rate fluctuations and production base in domestic and foreign markets in the statistical relationship between the configurations. But if the 
investor is a risk hedge, exchange rate fluctuations will lead to an increase in the share of production base in foreign countries, that is, FDI will increase.

RMB regionalization or internationalization can promote the development of foreign investment: First, the RMB regionalization or international financing investment facilitation effect. The foreign investment enterprises are financing in the international financial market, which will face the financing system and technical obstacles. It not only has high financing cost, but also has large financing and investment. Risk, which to some extent hindered the development of foreign investment. If a country's currency is internationalized or regionalized, it becomes a common currency in the region, and the foreign investment enterprise can solve the capital problem and reduce the financing cost by means of its own capital or financing from its own financial institutions. At the same time, it increased the financing channels of enterprises in overseas to help enterprises to better avoid the problem of currency mismatch, but also conducive to the investment in the region, to avoid restrictions on the size of foreign exchange liquidity, improve the efficiency of investment or financing, Promote foreign investment in a country. Second, the RMB regionalization or internationalization of the investment risk prevention effect. RMB regionalization or internationalization can effectively prevent and reduce the risk of investment exchange rate. On the one hand, it is reflected in the investment and operation process, the distribution of investment interests and the return of profits. The foreign exchange risk of settlement due to changes in foreign exchange rates. In particular, the economic instability of some host countries, in the case of inflation, led to the investment of assets shrinking, may make the investment income intangible losses. If the RMB is priced, it can reflect the operation status of the investment enterprises in a timely manner so as to facilitate the investment management of the Chinese enterprises in a timely manner and control and reduce the investment losses to the greatest extent. On the other hand, the RMB regionalization or internationalization is conducive to improving the competitiveness of the financial system, the large-scale circulation of the RMB, to promote the expansion of the scope of domestic financial institutions, to bring new business to domestic banks, but also makes the presence of domestic and foreign business Complementary financial institutions to deepen cooperation and improve the depth and breadth of the entire financial market. With the large-scale circulation of RMB, domestic and foreign demand for RMB risk hedge derivatives will be expanded, so that the innovation of foreign exchange products in financial markets will help to further avoid risks and facilitate foreign investment.

\section{Foreign exchange market exchange rate stability and currency internationalization effect}

The foreign exchange market and its derivative financial instruments can help foreign exchange participants to avoid foreign exchange risk, promote foreign trade and direct investment, and thus bring about the increase in welfare. It is generally assumed that the stability of the exchange rate is conducive to the improvement of trade and welfare, but P. Bcchetta and E. Wincoop (2000) show that there is no correspondence between the exchange rate system and trade and welfare levels. In general, trade and welfare will be higher under fixed and floating exchange rate regimes, depending on preferences and monetary policy rules under the two exchange rate regimes. There is no correspondence between trade levels and benefits between the two exchange rate regimes.

Relevant research suggests that the foreign exchange market is a means of promoting social and economic well-being (Frankel, 1999). Obstfeld and Rogoff (1995) established a standard open economic model and found that unanticipated monetary expansion in this model, both domestically and abroad, would increase the consumption and well-being of every resident at home and abroad. At the same time, scholars on the impact of exchange rate control on the welfare of the study, the results show that exchange rate control will lead to rent-seeking behavior, the emergence of high price fluctuations, hinder free trade, resulting in welfare losses. So the government should relax the exchange rate control, open the foreign exchange market. Kathleen Dorsainvil (2000) uses the ECM model in Haiti from 1985 to 1991 to establish a parallel market using the ECM model. The results show that the exchange rate control in Haiti has resulted in significant welfare losses.Before a lot of 
research on the exchange rate welfare effect, they believe that a flexible exchange rate system will effectively improve the welfare level, and alternative exchange rate system under certain conditions of the welfare effect is more significant. Dupusquier and Osakwe (2003), under the framework of Canzoneri and Henderson (1985), Buiter et al. (1995) and Lane (2000), extend the structural model of monetary policy to the Economic Community of West African States (ECOWAS) Alternative exchange rate system for the welfare effect of quantitative analysis.

The paper analyzes the impact of RMB regionalization or internationalization on the operation of China's financial system. Ba Shusong and Wu Bo (2008) analyzed the interaction between RMB internationalization and China's financial market, and analyzed the impact of RMB internationalization on China's financial the impact of the development of the industry. From a macro perspective, the internationalization of the RMB is conducive to the deepening of China's financial market, to promote the fostering and development of the RMB offshore market, to promote the internationalization of China's financial system and to ease the risk of currency mismatch. From the microscopic point of view, the internationalization of RMB can open up new profit space for China's banking industry, promote the development of China's stock market and bond market, and reduce the exchange rate risk of foreign exchange assets of China's insurance industry for a long time and promote the development of its international business. Some scholars believe that the RMB regionalization or internationalization of China's financial system will bring risks. Zhao Haikuan (2003) that the regionalization of RMB may be the risk of the operation of China's financial system, it may also increase the fake RMB, to bring economic losses to our country. Wang Yuanlong (2009) pointed out that the internationalization of the $\mathrm{RMB}$ to bring benefits to our country at the same time will also increase China's macro-control, domestic economic and financial stability and financial regulation of the difficulties, so that China faces "Triffin problems" and the risk of currency reversal.

\section{Conclusion}

This paper studies the welfare effect of the foreign exchange market from the aspects of the trade effect, the investment effect, the exchange rate stability and the internationalization effect of the foreign exchange market, and discusses the establishment and perfection of the foreign exchange market. For the trade, investment scale and economic development of our country and ASEAN countries So as to provide some reference for the reform and perfection of China's financial market and the process of RMB internationalization.

\section{Acknowledgments}

This research is supported by Natural Science Foundation of China (No.71363064) and the project of Philosophy and Social Science Research of Yunnan Province (No.JD2015YB23).

\section{References}

[1] Aleksander Aristovnik and Matevz Meze, The Economic and Monetary Union's Effect on (International) Trade: the Case of Slovenia before Euro Adoption[R], William Davidson Institute Working Paper Number 982 April 2010

[2] Andrew K.Rose, One Money, One Market: The Effect of Common Currencies on Trade [J]. Economic Policy, 2000, 30.

[3] Baldwin, R.E., The euro's trade effect [R]. European Central Bank. Working Paper Series, 2006, No.594. 